\title{
Consensual Unions in Latin America: Persistence of a Dual Nuptiality System*
}

TERESA CASTRO MARTIN**

\section{INTRODUCTION}

Family formation patterns have undergone significant transformations in the past decades. Among recent trends, the rise in cohabitation has attracted particular attention in the demographic and sociological literature (Bumpass et al., 1991). Most studies have focused on Western societies, hence the prevailing tendency to regard cohabitation as an outcome of the modernization process. Its increase has generally been linked to the search for personal autonomy and diminishing acceptability of institutional regulation in the sphere of family life that have driven the "second demographic transition" (van de Kaa, 1987; Inglehart, 1997). But consensual unions are not exclusive to the developed world. Their prevalence is high in many developing regions, such as Latin America and the Caribbean (Quilodrán 1999; De Vos, 2000), and some parts of sub-Saharan Africa (Meekers, 1991; Thiriat, 1999). Moreover, the social meaning attached to these unions as well as their historical, socioeconomic and cultural roots differ largely from those observed in the developed world.

The coexistence of formal marriages and consensual unions has long been a distinctive feature of nuptiality patterns in Latin America and the Caribbean (Camisa, 1978; United Nations, 1990). In some countries, the proportion of consensual unions even surpasses that of legal marriages, particularly at young ages (Quilodrán, 1985). Although some couples eventually formalize their union (Goldman and Pebley, 1981), a large segment of unions are never "legalized", implying that a considerable proportion of families are built outside the traditional marriage framework. Whereas cohabitation in developed societies usually serves as a trial period preceding marriage or an alternative to singlehood (Rindfuss and VanDenHeuvel, 1990), consensual unions in Latin America are best described as surrogate marriages. The absence of a formal ceremony or a legal contract does not preclude full social recognition or condition childbearing behaviour.

Consensual unions have been an integral component of the Latin American family system for centuries (Gonzalbo Aizpuru, 1998). Some historical roots can be traced back to the colonial period, when male colonizers, largely outnumbering women, found in the "amancebamiento" a means of sanctioning sexual unions with indigenous women (McCaa,

\footnotetext{
* This is a revised and updated version of the paper, Marriages Without Papers in Latin America, presented at the IUSSP International Population Conference, Beijing, 11-17 October 1997, and printed in the Conference proceedings, Vol. 2, pp. 941-960. Liège: International Union for the Scientific Study of Population

** Instituto de Economía y Geografía, CSIC, Madrid, tcastro@ieg.csic.es
} 
1994). Formal marriage guaranteed the intergenerational transmission of property within the Spanish elite whereas common-law marriages, built simply on mutual consent, were typical among the mestizo population (Lavrin, 1989; Folbre, 1991). Since marriage rites were highly elaborate and costly during the colonial period and through most of the nineteenth century, many couples deferred or forwent marriage and instead formed consensual unions, with very high proportions - possibly 30 to 50 per cent - of births occurring out of wedlock (Kuzneof and Oppenheimer, 1985). Although the imposition of the Catholic marriage model was a main concern of both the Church and the State (Pescador, 1988), their success was only partial in a culturally and ethnically mixed society and, in some cases, they even hindered it through strict endogamous marriage codes (Nazzari, 1996). In rural areas, the scarcity of civil and ecclesiastic authorities may also have prevented couples from seeking legal or religious sanction for their unions. However, although informal unions were widespread and socially recognized, they were rarely conferred the same prestige as formal marriages.

Besides the legacy of a long historical tradition, contemporary socioeconomic conditions are also likely to be part of the explanation for the high prevalence of consensual unions in the region. Unlike many developed countries, where cohabitation emerged among the urban educated sectors of society, consensual unions in Latin America are more prevalent among disadvantaged social strata, suggesting that economic costs may act as a deterrent on marriage. Formal marriage, especially a church wedding, is generally regarded as more desirable, because of its higher security benefits for the woman and the children, its symbolic commitment of endurance, and a more clearly defined social position with respect to the partner and the in-law family. But consensual unions are simpler to initiate and less costly (Greene, 1991). Some segments of the population may also feel alienated from the legal system, lack access to it, or perceive no practical benefits from legal contracts over implicit agreements. Informal unions may also serve as a mechanism for adjustment to a situation of disequilibrium in the marriage market (Greene and Rao, 1995).

Although most consensual unions resemble formal marriages, except that spouses elude registering or paying the relatively high costs of a wedding ceremony, they are characterized by higher instability (Goldman, 1981; Goode, 1993), partly stemming from their non-binding legal status. Their higher level of dissolution exerts a large influence on the family and household structure in the region (De Vos, 1987), particularly on the prevalence of femaleheaded households (De Vos and Richter, 1988; United Nations, 1995; Arias and Palloni, 1999), and also on the welfare of women and children (Richter, 1988), since they often entail lower male responsibility towards the family.

It should be borne in mind that consensual unions are not a homogeneous category, but comprise a wide variety of partnership situations (De Vos, 1999), which range from an alternative to singlehood (Jelin, 1992), a strategy to confront single motherhood, a prelude to a marriage deferred by economic difficulties or legal constraints -e.g. awaiting divorce, a frame for secondary relationships among already married persons, to a long-lasting surrogate marriage (Quilodrán, 1999). In some countries, a "modern" type of consensual union, which resembles the pattern observed in developed societies, is also emerging among well-educated urban women (Parrado and Tienda, 1997). However, the large majority of consensual unions correspond to the "traditional" type, and can be best characterized as a substitute for formal marriage among social strata with low education and poor economic prospects. 
This study aims at documenting the variety of nuptiality forms in the Latin American region. First, the current prevalence of consensual unions as well as recent trends are described for all Latin American countries. Afterwards, using DHS data collected in the late 1980s for nine countries, the demographic and socioeconomic profiles of women in formal and informal unions are compared, paying special attention to their childbearing behaviour. Lastly, the factors associated with being in a consensual union versus a legalized marriage are assessed within a multivariate framework. Although including a large number of countries naturally limits the scope of the analysis, the goal of documenting levels, trends and correlates of consensual unions for the whole region is to provide a broad baseline for future in-depth research on this important but largely neglected domain of family behaviour.

\section{DATA}

The study of consensual unions has traditionally been hampered by paucity of data. Consensual unions, by definition, are not reported in any register and therefore remain outside the realm of vital registration systems (Arretx, 1971). Another basic source of information on nuptiality, population censuses, were initially aimed at capturing de jure instead of de facto marital status and usually recorded common-law spouses as single. Although censuses have gradually incorporated consensual unions as an additional marital status category', these unions are often underreported (Camisa, 1978).

Knowledge on the prevalence of cohabitation and its role in the family formation process has expanded in the past decades largely due to the increasing availability of marital history data from demographic surveys. Even if some women will fail to report a consensual union, carefully designed and probed survey questions on marital status are more likely to elicit a true response than censuses. The World Fertility Survey (WFS), for instance, collected in the 1970s detailed marital histories from all women ever-in-union, including information on union type, date of onset, date of dissolution and reason for dissolution for each union.

Unfortunately, DHS-I did not collect complete retrospective marital histories. The information available is confined to date of first union, current union type (but not its date of initiation if not a first union) and number of previous unions (but not their type) ${ }^{2}$. Therefore, some important aspects of nuptiality, such as the process of union legalization and union dissolution, cannot be adequately modelled. More importantly, children cannot be properly matched to the marital histories of their mothers. Despite these limitations, some valuable knowledge on nuptiality patterns can be gained by focusing on current conjugal status. The criteria used by DHS to define an informal union were largely subjective. Respondents were explicitly asked to identify their relationship to another adult in the household as "unmarried partner". Although data were collected in a comparable manner in all countries, cultural norms and the social recognition granted to informal unions may affect the way union status is reported ${ }^{3}$ (Blanc and Rutenberg, 1990).

\footnotetext{
' Some Latin American countries, like Mexico, included a separate category for consensual unions in their marital status classifications as early as 1930, but most of them only did so as from 1950 .

2 In DHS-II and DHS-III, for countries using a Model A questionnaire (high contraceptive prevalence countries), a monthly marriage history was collected for the 5 to 6 years prior to the survey.

${ }^{3}$ A recent study of informal unions in Central America, however, found a remarkable degree of consistency between survey and census data, and between male and female census classifications of union status, suggesting that the amount of misreporting is probably small (Castro Martin, 1999).
} 
In this study, the prevalence and trends of consensual unions are assessed for all countries in the Latin American region ${ }^{4}$, based on both census and survey data, but the analytical part of the study focuses on nine Latin American countries that were surveyed by DHS in the late $1980 \mathrm{~s}^{5}$ : Bolivia, Brazil, Colombia, Dominican Republic, Ecuador, El Salvador, Guatemala, Mexico and Peru.

\section{PREVALENCE OF CONSENSUAL UNIONS: LEVELS, TRENDSANDAGE PATTERNS}

Figure 1 presents the current prevalence of consensual unions in all Latin American countries. The data compiled indicate that informal unions are particularly widespread in the Caribbean (Catasfis, 1992) and the Central American subregion (Castro Martin, 1999). In fact, in the Dominican Republic, El Salvador, Honduras, Nicaragua and Panama, consensual unions outnumber legal marriages. A somewhat lower level, but still remarkably high -in the 25 to 50 per cent range - is found in Cuba, Guatemala, Colombia, Ecuador, Paraguay, Peru and Venezuela. At the lower end of the spectrum, the prevalence of informal unions is below 25 per cent in Costa Rica, Mexico, Argentina, Bolivia, Brazil, Chile and Uruguay.

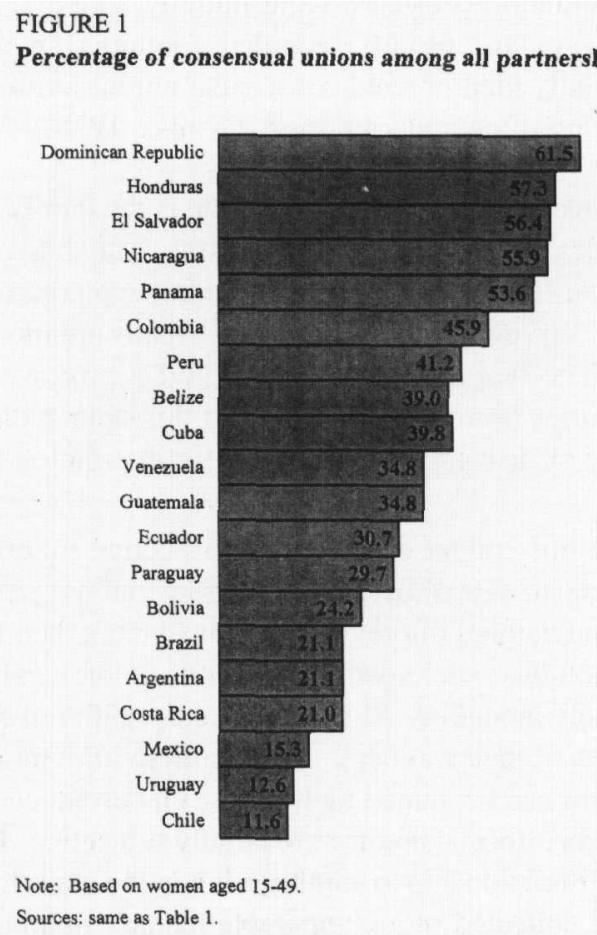

The levels recorded confirm that, throughout Latin America, a large segment of partnerships remain outside the legal marriage framework. The two types of unions registered and unregistered - coexist side by side in the region, reflecting the quasi-institutionalization of

\footnotetext{
${ }^{4}$ Caribbean countries with Hispanic heritage -Cuba and the Dominican Republic- are also included.

${ }^{s}$ The analysis is confined to DHS-1 in order to examine the profile of consensual unions in a similar time period the late 1980s-. However, the description of levels and trends of consensual unions in the whole region makes use of more recent data, compiled from censuses and latest survey reports.
} 
a dual nuptiality system. It should be noted that, since a considerable proportion of consensual unions are short-lived - because of either dissolution or legalization, there might be a large discrepancy between cross-sectional levels and lifetime experience of cohabitation, whose level would presumably be much higher ${ }^{6}$. It should also be kept in mind that the prevalence measured at the time of census or survey includes second and higher order unions - which are less likely to be legally sanctioned.

Although the dual nuptiality system prevails in the whole region, the relative weight of each type of union varies significantly across countries. The proportion of partnerships built on a consensual basis ranges from 61.5 per cent in the Dominican Republic to 11.6 per

\section{TABLE 1}

PERCENTAGE OF CONSENSUAL UNIONSAMONG WOMEN CURRENTLY IN PARTNERSHIP, BYAGE GROUP. MOST RECENT DATA SOURCE.

\begin{tabular}{llllll}
\hline & & & \multicolumn{3}{c}{ Age group } \\
& Source & Year & $15-24$ & $25-34$ & $35-49$ \\
\hline Caribbean & & & & & \\
Cuba & Survey & 1995 & 48.6 & 42.0 & 33.0 \\
Dominican Republic & DHS-III & 1996 & 76.7 & 59.4 & 53.4 \\
Central America & & & & & \\
Belize & RHS & 1991 & 50.0 & 39.0 & 28.0 \\
Costa Rica & RHS & 1993 & 33.1 & 19.5 & 18.2 \\
El Salvador & RHS & 1993 & 71.0 & 53.8 & 46.8 \\
Guatemala & DHS-III & 1995 & 47.2 & 32.8 & 28.7 \\
Honduras & RHS & 1996 & 74.4 & 54.6 & 46.6 \\
Mexico & Census & 1990 & 24.7 & 13.9 & 11.0 \\
Nicaragua & DHS-III & 1998 & 71.5 & 53.3 & 45.9 \\
Panama & Census & 1990 & 75.4 & 54.5 & 46.9 \\
South America & & & & & \\
Argentina & Census & 1991 & 37.9 & 20.8 & 16.3 \\
Bolivia & DHS-III & 1998 & 51.7 & 23.5 & 13.4 \\
Brazil & DHS-III & 1996 & 36.5 & 21.8 & 15.2 \\
Chile & Census & 1992 & 16.6 & 11.3 & 10.1 \\
Colombia & DHS-III & 1995 & 66.6 & 49.1 & 32.7 \\
Ecuador & RHS & 1994 & 40.8 & 30.3 & 24.6 \\
Paraguay & RHS & $1995 / 96$ & 49.5 & 28.4 & 20.6 \\
Peru & DHS-III & 1996 & 69.3 & 44.5 & 25.1 \\
Uruguay & Census & 1985 & 18.6 & 13.6 & 10.0 \\
Venezuela & Census & 1990 & 42.4 & 34.8 & 30.4 \\
\hline
\end{tabular}

Note: DHS: Demographic and Health Survey, RHS: Reproductive Health Survey.

Sources: DHS country reports (Macro International Inc.), RHS country reports (US Centers for Disease Control) and US Census Bureau International Data Base.

6 As an illustration of the extent of the discrepancy between current experience and lifetime experience, in the U.S. 12.9 per cent of adults aged 25-29 are currently cohabiting, as compared to 49 per cent in the same age group who have ever cohabited (Bumpass, 1995). 
cent in Chile. The countries with a high prevalence of informal unions tend to display an early age pattern of marriage (United Nations, 1990), rank low in the Human Development Index (UNDP, 1998), and some of them have a large proportion of indigenous population ${ }^{7}$ (Peyser and Chackiel, 1994) or of African descent. However, causal inference based on country-level data is well known to be inadequate, and there are several outliers to these broad associations which attest to the difficulty of establishing a clear-cut typology that would help us to understand the observed variation in the prevalence of informal unions. Besides the particular historical heritage of each society, there is possibly an interaction between socioeconomic dimensions and factors of a more cultural nature, such as ethnicity or family value systems.

In every country, the highest prevalence of consensual unions corresponds to the youngest age group. According to Table 1, in 8 of the 19 countries examined, the proportion of women aged 15 to 24 in informal marriages exceeds that in formal marriages, and in some of those countries - the Dominican Republic, El Salvador, Honduras, Nicaragua, Panama, Colombia and Peru, consensual unions account for more than two-thirds of all marital unions among young women. The ratio of consensual unions to formal marriages diminishes with age, which might indicate changing nuptiality patterns by cohort, different choices of union according to life cycle stage, or a tendency to formalize relationships as time passes. However, although consensual unions become less prevalent at advanced ages, they cannot be accurately portrayed as a conjugal form confined to youth. Among the 25 to 34 age group, for instance, consensual unions make up approximately one-half of all unions in the Dominican Republic, El Salvador, Honduras, Nicaragua, Panama and Colombia. Moreover, consensual unions continue to represent about half of all unions in the 35 to 49 age group in all those countries, except Colombia. Informal marriages, hence, remain common at later stages of the life cycle, suggesting that the process of union legalization is far from generalized. This pattern departs from that observed in many developed countries, where cohabitation usually constitutes an early stage in the family formation process and decreases sharply at older ages $^{8}$.

Table 2 depicts recent developments in the prevalence of consensual unions, based on a fairly comprehensive list of data sources from 1970 to date. Although trend information might be partly biased because of differences in coverage and quality across data sources particularly among censuses and surveys, the high degree of consistency of data collected over similar dates and the coherence of the tendency over time point to the reliability of the evolution portrayed. The general trend is characterized by either stability or moderate rise in the proportion of consensual unions. In 9 countries, this proportion remained stable or experienced a change of less than 5 percentage points (Cuba, Costa Rica, El Salvador, Honduras, Mexico, Panama, Ecuador, Uruguay and Venezuela), and in 8 countries the increase was in the range of 5 to 15 percentage points (Dominican Republic, Nicaragua, Argentina, Bolivia, Brazil, Chile, Paraguay and Peru). Since consensual unions were more likely to go

\footnotetext{
Although the countries with the largest proportion of indigenous population (between 40 and 60 per cent), Bolivia, Ecuador, Guatemala and Peru, also have a high overall prevalence of consensual unions, DHS individual data show no significant differences in union type by ethnic background in the countries for which this information is available.

"The increasing prevalence of cohabitation after separation or divorce has recently made this decrease by age less marked (Kiernan, 1996).
} 
TABLE2

TRENDS IN THE PERCENTAGE OF CONSENSUAL UNIONS AMONG WOMEN IN PARTNERSHIP. 1970s-1990s.

\begin{tabular}{|c|c|c|c|c|c|c|c|}
\hline & Source & Year & $\%$ & & Source & Year & $\%$ \\
\hline \multicolumn{8}{|l|}{ Caribbean } \\
\hline \multirow{3}{*}{ Cuba } & Census & 1970 & 40.9 & \multirow[t]{3}{*}{ Bolivia } & DHS-I & 1989 & 17.5 \\
\hline & Census & 1981 & 37.5 & & DHS-II & 1994 & 22.1 \\
\hline & Survey & 1995 & 39.8 & & DHS-III & 1998 & 24.2 \\
\hline \multirow[t]{6}{*}{ Dominican Rep } & Census & 1970 & 51.8 & \multirow[t]{4}{*}{ Brazil } & Census & 1970 & 7.5 \\
\hline & WFS & 1975 & 62.4 & & Census & 1980 & 12.7 \\
\hline & Census & 1981 & 57.0 & & DHS-I & 1986 & $15.3^{*}$ \\
\hline & DHS-I & 1986 & 62.6 & & DHS-III & 1996 & 21.1 \\
\hline & DHS-II & 1991 & 59.7 & \multirow[t]{2}{*}{ Chile } & Census & 1970 & 5.0 \\
\hline & DHS-III & 1996 & 61.5 & & Census & 1982 & 7.1 \\
\hline \multicolumn{5}{|l|}{ Central America } & Census & 1992 & 11.6 \\
\hline \multirow[t]{4}{*}{ Costa Rica } & Census & 1973 & 16.7 & \multirow[t]{4}{*}{ Colombia } & Census & 1973 & 19.8 \\
\hline & WFS & 1976 & 18.5 & & WFS & 1976 & 26.8 \\
\hline & Census & 1984 & $19.0^{* *}$ & & Census & 1985 & 31.5 \\
\hline & RHS & 1993 & 21.0 & & DHS-I & 1986 & 35.6 \\
\hline \multirow[t]{4}{*}{ El Salvador } & Census & 1971 & 52.6 & & DHS-II & 1990 & 38.4 \\
\hline & DHS-I & 1985 & 57.6 & \multirow{8}{*}{ Ecuador } & DHS-III & 1995 & 45.9 \\
\hline & Census & 1992 & 51.8 & & Census & 1974 & 27.4 \\
\hline & RHS & 1993 & 56.4 & & WFS & 1979 & 29.6 \\
\hline \multirow[t]{5}{*}{ Guatemala } & Census & 1973 & 54.0 & & Census & 1982 & 29.2 \\
\hline & Census & 1981 & 45.9 & & DHS-1 & 1987 & 32.8 \\
\hline & DHS-I & 1987 & $40.1^{*}$ & & RHS & 1989 & 26.5 \\
\hline & Census & 1990 & $37.4 *$ & & Census & 1990 & 29.6 \\
\hline & DHS-III & 1995 & 34.8 & & RHS & 1994 & 30.7 \\
\hline \multirow[t]{3}{*}{ Honduras } & Census & 1974 & 56.1 & \multirow[t]{6}{*}{ Paraguay } & Census & 1972 & 24.5 \\
\hline & Census & 1988 & 50.1 & & WFS & 1979 & 25.3 \\
\hline & RHS & 1996 & 57.3 & & Census & 1982 & 25.4 \\
\hline \multirow[t]{5}{*}{ Mexico } & Census & 1970 & 16.1 & & DHS-II & 1990 & 23.0 \\
\hline & WFS & 1977 & 14.3 & & Census & 1992 & 29.2 \\
\hline & Census & 1980 & 14.4 & & RHS & 1995/96 & 29.7 \\
\hline & DHS-I & 1987 & 15.5 & \multirow[t]{6}{*}{ Peru } & Census & 1972 & 29.0 \\
\hline & Census & 1990 & 15.3 & & WFS & $1977 / 78$ & 23.9 \\
\hline \multirow[t]{3}{*}{ Nicaragua } & Census & 1971 & 40.8 & & Census & 1981 & 26.7 \\
\hline & RHS & $1992 / 93$ & 56.3 & & DHS-I & 1986 & 30.9 \\
\hline & DHS-III & 1998 & 55.9 & & DHS-I & $1991 / 92$ & 32.1 \\
\hline \multirow[t]{4}{*}{ Panama } & Census & 1970 & 56.0 & & DHS-III & 1996 & 41.2 \\
\hline & WFS & $1975 / 76$ & 50.2 & \multirow[t]{2}{*}{ Uruguay } & Census & 1975 & 8.8 \\
\hline & Census & 1980 & 53.5 & & Census & 1985 & 12.6 \\
\hline & Census & 1990 & 53.6 & \multirow[t]{2}{*}{ Venezuela } & Census & 1971 & 32.9 \\
\hline \multirow{4}{*}{$\begin{array}{c}\text { South America } \\
\text { Argentina }\end{array}$} & & & & & WFS & 1977 & 33.7 \\
\hline & Census & 1970 & 10.5 & & Census & 1981 & $33.4^{*}$ \\
\hline & Census & 1980 & 12.3 . & & Census & 1990 & 34.8 \\
\hline & Census & 1991 & 21.1 & & & & \\
\hline
\end{tabular}

Notes: WFS: World Fertility Survey, DHS: Demographic and Health Survey, RHS= Reproductive Health Survey Other Surveys: Encuesta Nacional de Migraciones Internas 1995 (Oficina Nacional de Estadistica, Cuba). * Women 15-44; ** Women 20-49. The rest of the estimates are based on women aged 15-49.

Sources: DHS country reports (Macro International Inc.), RHS country reports (US Centers for Disease Control) and US Census Bureau Internationl Data Base. 


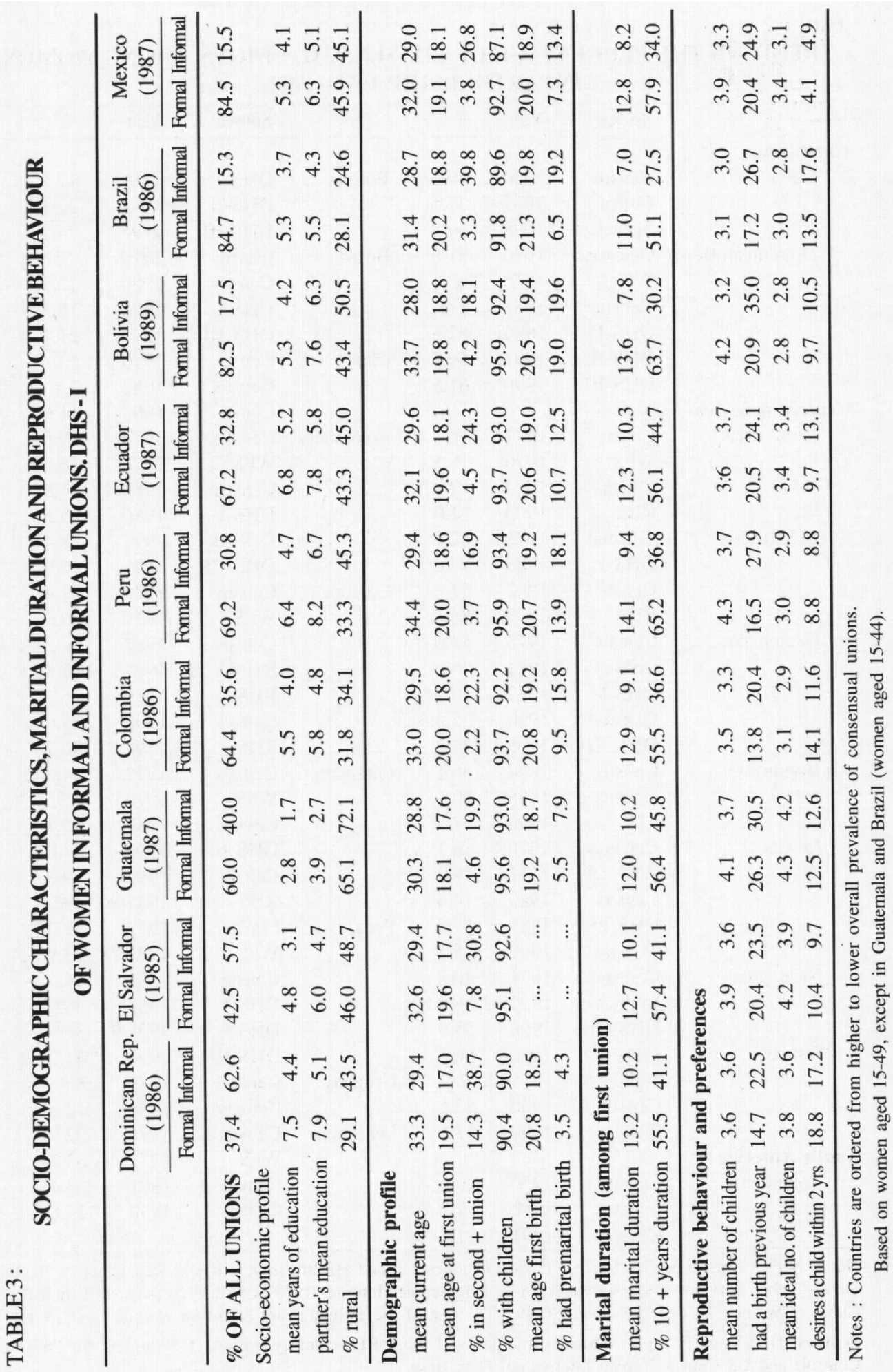


unreported in the past, the evidence of an upward trend should be taken with some caution. Only one country, Colombia, experienced a major increase (26 percentage points, doubling the level recorded in the early 1970s), and only Guatemala experienced a sizable reduction in the prevalence of informal unions (their proportion declined by one-third). Hence, unlike developed countries, which experienced a dramatic rise in cohabitation during the past two decades (Kiernan, 1996), the trend observed in the large majority of Latin American countries suggests only moderate departures from a level that was already high in 1970.

\section{PROFILEOF WOMENIN FORMAL AND INFORMAL UNIONS}

Table 3 compares the profiles of women in formal and informal marriages with regard to their socioeconomic status, demographic characteristics, marital duration patterns and childbearing behaviour in nine Latin American countries based on DHS-I data. Many of the associations that appear in this descriptive table will subsequently be reassessed in a multivariate framework.

\section{Socio-economic profile}

Earlier studies have documented that informal marriages are more prevalent among socially and economically disadvantaged strata in the Latin American region (Michielutte et al., 1973). The data in Table 3 confirm that, in all countries examined, women in consensual unions are less educated, have less educated partners, and are more likely to live in rural areas (except in Brazil and Mexico) than their counterparts in formal marriages. The average educational attaimnent of women in consensual unions is lower by approximately one year of schooling in Guatemala, Colombia, Bolivia and Mexico, by nearly two years in El Salvador, Peru, Ecuador and Brazil, and by more than three years in the Dominican Republic. Likewise, the educational attaimnent of their partners is on average 1 to 3 years lower than that of the spouses of legally married women.

\section{Demographic profile}

Prior studies have documented that the age at which women initiate consensual unions is younger than the age at which they enter legal marriage (Camisa, 1978). According to the data presented in Table 3, women currently in a consensual union are on average younger than those in a formal marriage and entered their first union at an earlier age. hi most countries examined, the mean age at first union is 1 to 2 years younger among consensually married women than among legally married women. Another distinctive feature is that a considerable proportion of women currently in an informal marriage have had a previous union (ranging from 17 per cent in Peru to 40 per cent in Brazil), whereas most women in a legal marriage are in their first union.

Regarding their reproductive history, the large majority of women (above 90 per cent in most countries) in both consensual and formal marriages have had at least one child. The proportion of childless women is slightly higher among those in consensual unions, but differentials are small (mostly within 1 to 3 percentage points). Although these results clearly indicate that whether a union is legalized or not does not actually affect women's 
childbearing status, reproductive patterns in both types of union are not entirely similar. The onset of childbearing, for instance, is earlier among women in consensual unions than among those in legal marriages: their mean age at first birth is 1 to 2 years younger. Also, a larger proportion of first births to consensually married women were born prior to forming a union.

\section{Duration patterns}

Consensual unions in Latin America have been documented to be more likely to dissolve than formal marriages (Goldman, 1981; Rao and Greene, 1991). Several processes underlie the higher dissolution rates of consensually formed unions. On the one hand, cohabiting couples often legalize their relationship through civil or religious marriage (Goldman and Pebley, 1981). The consensual union thus ends as such, even if the couple continues together. Union legalization also involves a selectivity process, since the more committed couples are more likely to take the step of formalizing their relationship, therefore leaving in the pool of consensual unions a higher proportion of more fragile relationships. On the other hand, whereas annulling a religious marriage might be practically unfeasible and dissolving a civil marriage might be subject to social disapproval and entail substantial costs, partnerships based on mutual agreement, involving no legal obligations, can be dissolved relatively easily.

Since complete retrospective marital histories are not available in DHS data, it is not possible to compare the rate of dissolution of formal versus informal marriages. Some crude indirect evidence can be gained by looking at the duration patterns of current unions, although the analysis has to be confined to first unions because marital duration of higher order unions cannot be ascertained from DHS-I data. Table 3 presents the mean marital duration for current formal and informal first unions. As expected, the average duration is shorter for consensual unions. Differentials range from about 2 years in El Salvador, Guatemala and Ecuador to about 6 years in Bolivia. Although other factors may account for these differences, such as divergences in age structure and the process of union legalization, they provide some indication that formal marriages tend to last longer. This does not mean, however, that all consensual unions are shortlived and can be regarded as a transient stage which eventually leads to either legalization or rupture. Data on the proportion of consensual unions with a duration of 10 or more years indicate that, although this proportion (roughly $30-45$ per cent) is significantly lower than that for legal marriages ( $50-65$ per cent), the number of long-lasting relationships is by no means negligible.

\section{Childbearing behaviour}

Demographic studies on union type in Latin America and the Caribbean have traditionally focused on its impact on fertility (Stycos, 1968; Henriques, 1982; Burch, 1983; Ebanks and Loaiza, 1989; Glaser, 1994; Rosero-Bixby, 1996). Various hypotheses have been put forward in the literature. Because of higher levels of marital disruption, women in consensual unions usually spend longer periods outside a partnership, facing lower exposure to pregnancy risks, and hence could be expected to have lower overall fertility (Onaka, Yaukey and Chevran, 1977). Marital instability, however, could also act as a fertility enhancer. The higher disruption 
rates of informal unions often result in a larger number of partnerships in which a woman engages during her reproductive life. Since children are perceived as important for creating a firmer bond within a consensual couple, women may desire to have at least one child with each new partner. Multiple partnerships would thus have a positive effect on lifetime fertility (Lightbourne and Singh, 1982). Also, since consensual unions are more prevalent among low-educated and economically disadvantaged women, it is possible that these socioeconomic factors, irrespective of union type, may account for most of the observed fertility differentials (Trovato and Taylor, 1980; Henriques, 1982).

Although past studies have focused on measuring and interpreting fertility differentials by union type, it might be the similarity in childbearing behaviour between women in consensual and legal marriages that should be highlighted. It was noted earlier that the large majority of women in consensual unions (around 90 per cent in most countries) had borne at least one child, suggesting that childbearing is not confined to formal marriages but takes place ordinarily in unions which are not legally sanctioned. In order to explore further to what extent the childbearing experience of women in consensual unions resembles that of women in formal marriages, the lower panel in Table 3 presents several indicators of reproductive behaviour and preferences. The mean number of children ever born is lower for women in consensual unions than women in legal marriages, except in Ecuador and the Dominican Republic. However, observed differentials in current family size are relatively small, ranging from less than 0.4 children in El Salvador, Guatemala, Colombia and Brazil to 1 child in Bolivia. Taking into account that women in informal marriages are on average younger and have shorter marital durations, these differentials in cumulative fertility become even less salient.

Since a considerable proportion of consensual unions are second or higher order unions, it is possible that children were born in previous unions, which could have been formal marriages. Likewise, some women currently in a legal marriage may have started their relationship as a consensual union. In order to relate fertility more precisely to current union type, Table 3 presents an indicator of recent childbearing experience: the percentage of women who had a child in the year prior to the interview. Given the brief interval, we can assume rather confidently that the child was born within the current union. The data show that,. concerning recent childbearing experience, it is women in consensual unions who have higher fertility in all countries, although their younger age structure may partly account for this pattern.

Indicators of reproductive preferences can provide some further insight on whether women in consensual unions foresee their reproductive lives differently than legally married ones. According to Table 3, the average ideal family size is very similar for women in formal and informal marriages. Another indicator of reproductive preferences, more closely linked to current union type, is the desire to have a child in the next two years. According to the data presented, no single pattern holds for all countries but, overall, observed differentials are small.

In short, although the data available do not allow a refmed test of the impact of union type on fertility, all evidence points towards its minor relevance. The reproductive preferences 


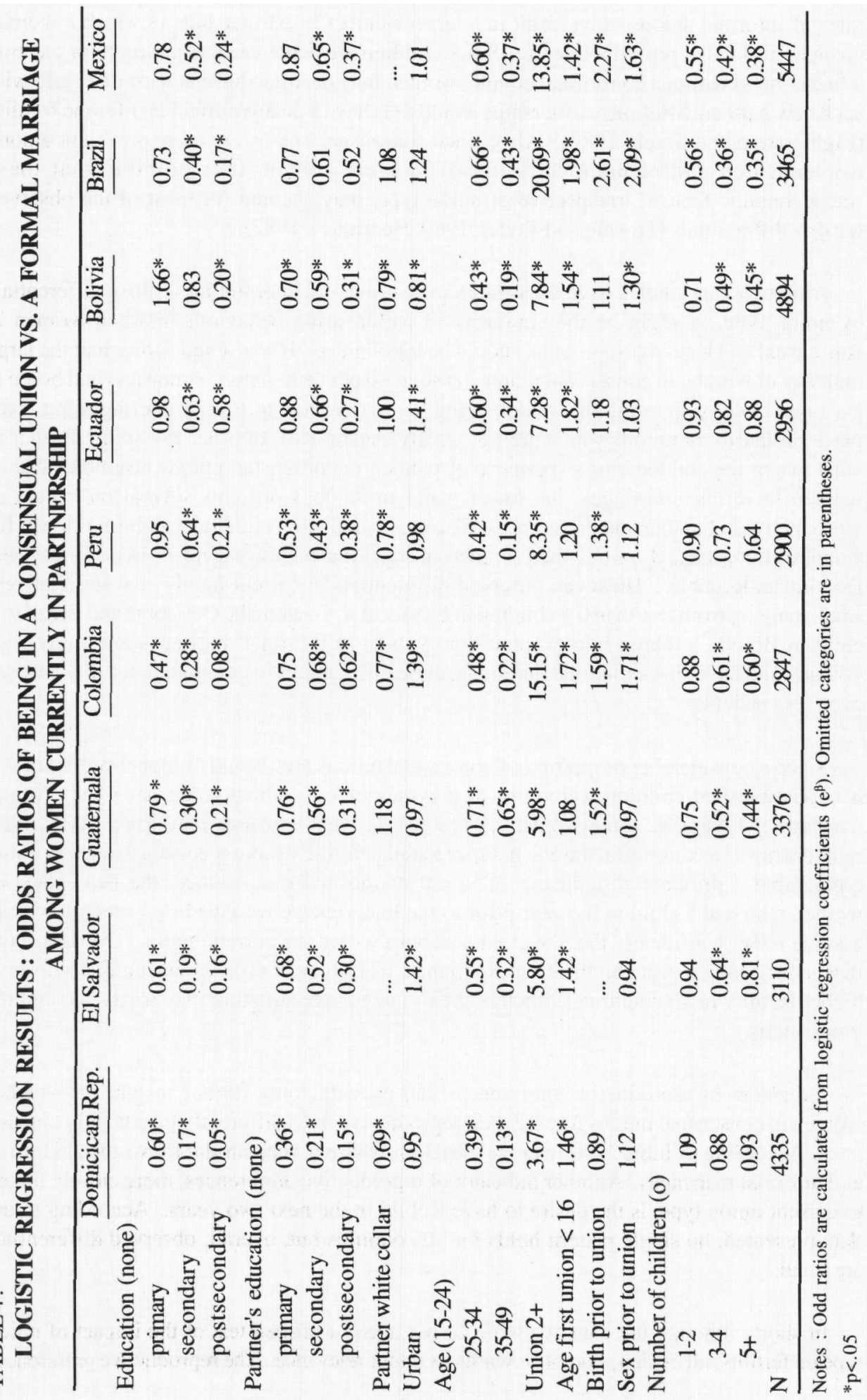


and behaviour of women in consensual unions do not fit into the notion of cohabitation as a transitory stage or "trial marriage" that tends to be formalized once a child arrives; instead, they imply a parallel form of marriage, where childbearing is commonplace. This pattern differs from that found in many developed countries, where childless cohabitation is still predominant, and where pregnancy is a major factor inducing union legalization (Manning, 1993).

\section{FACTORSASSOCIATED WITH BEING INAN INFORMAL UNION VERSUS A FORMAL UNION}

The previous section compared the socioeconomic and demographic profile of women in consensual and legal marriages, as well as their reproductive preferences and behaviour. Since some of these factors are closely interrelated, they are reexamined next in a multivariate framework. Due to the lack of complete retrospective marital histories, we cannot use event history analysis to estimate the probability of entering a consensual or legal union within a competing-risk framework. Instead, we will focus on current union status. A logit regression model is used to assess which socioeconomic and demographic factors are significantly associated with being in a consensual union versus a formal marriage among women currently

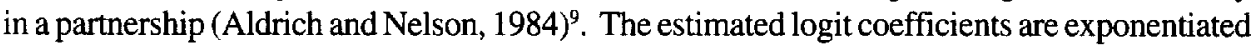
in order to present the results in terms of odds ratios (DeMaris, 1995).

In line with previous studies that have documented that Latin American women in consensual unions tend to belong to low socioeconomic strata, the results in Table 4 show that education decreases the odds of being in a consensual union as opposed to a formal marriage. Although in some countries (Peru, Ecuador, Brazil and Mexico), no significant differences are found between women with no schooling and those with primary schooling, secondary and postsecondary schooling significantly reduce the chances of being in an informal marriage in all countries. Education could be taken as a proxy for socioeconomic status, which is related to property ownership and thus with the perceived need to formalize a marriage (Castro Martin and Juárez, 1995). Furthermore, higher educational attainment might provide greater bargaining power to a woman in order to negotiate a marital arrangement on the terms she wishes.

The effect of partner's education is comparatively weaker than women's education, but still important. Except for Brazil, where it shows no relevance, in the rest of the countries, the higher the educational attainment of her partner, the less likely that a woman is in a consensual union. Another indicator of family socioeconomic status, partner's occupation ${ }^{10}$, is related to current union type in only four countries. Women whose partners have a professional or white-collar occupation are less likely to live in a consensual union in the Dominican Republic, Colombia, Peru and Bolivia, but the association is not statistically significant in the rest of

\footnotetext{
${ }^{9}$ Since the logit analysis only includes women currently in union, results should be interpreted as estimates of the conditional probability of remaining in an informal union versus a formal union once the woman has entered a partnership.

${ }^{10}$ Data on women's occupation are not available and female current work status was not found to be significantly related to union type in preliminary analyses. It should be noted that in the Latin American context, women's participation in the labour force, largely concentrated in low skill and domestic occupations, is not necessarily a sign of greater female autonomy (Parrado and Tienda, 1997).
} 
the countries, once the education of both spouses is taken into account.

The bivariate associations between place of residence and union type in the previous section showed that, in most countries, consensual unions tend to be more prevalent in rural areas. Although urban areas may offer greater anonymity and tolerance towards consensual unions, it could be argued that in rural communities, greater social pressures may force fathers to acknowledge their obligations to children, regardless of the nature of the relationship, and thus make the need for legalization less relevant. However, in the multivariate model, both the strength and the direction of the association between place of residence and union type change. Although Bolivian women living in rural areas are more likely to be in a consensual union, in El Salvador, Colombia and Ecuador, it is urban residence that is associated with a higher likelihood of being in an informal union. In the rest of the countries, place of residence has no significant influence on union type, once the rest of the factors have been controlled.

Age serves as an indicator of both cohort membership and stage in the life cycle. The results of Table 4 indicate that the odds of being in a consensual union decrease significantly with age. After controlling for age at first union, union order and parity, age remains as one of the key factors determining current union status across all countries examined. The observed age pattern may reflect the higher propensity of young persons to opt for a consensual union as well as the gradual process of legalization of consensually formed unions as partners mature. However, since we are using current status data, we cannot readily infer an upward cohort trend in informal nuptiality.

In all countries examined, union order is the covariate with the greatest impact on current union type. Women in their second or higher order union are much more likely to be in an informal marriage than women in their first union. In Brazil and Colombia, for instance, being in a second or subsequent union increases the odds of living in a consensual union by a factor of 21 and 15 respectively. This may be related to the difficulty of obtaining a divorce ${ }^{11}$ and the impossibility of a second religious marriage for Catholics. It might also indicate that cohabitation serves to screen potential partners among the more risk averse who have already experienced marital disruption.

With regard to the influence of the timing of union formation, in all countries, except Guatemala and Peru, a young age at entry into first union is associated with a higher likelihood of currently being in a consensual union. Also, in Guatemala, Colombia, Peru, Brazil and Mexico, women who had a premarital birth are more likely to be in a consensual union, even after taking education into account.

Since there are no attitudinal questions in DHS data regarding perceptions of marriage or cultural values, we have to rely on second-hand information. If a woman reports to have been sexually active prior to her first union, this could be taken as a proxy for non-traditional attitudes, and she could be hypothesized to be more prone to live in a consensual partnership.

\footnotetext{
${ }^{11}$ Financial costs, social stigma and the complexity of the legal process usually act as deterrents to divorce. In some countries, divorce was not legalized until recently (in 1987 in Argentina and in 1991 in Paraguay) and it remains illegal in Chile.
} 
Despite the importance given to female premarital chastity in the cultural and religious tradition of the region (Salles and Tuirán, 1997), recent data reveal that premarital sexual activity is increasingly common (Rosero-Bixby, 1991). According to Table 4, reported sexual activity prior to union is associated with a higher likelihood of currently being in a consensual union in Colombia, Bolivia, Brazil and Mexico. In the rest of the countries, no significant association was found.

The earlier descriptive analysis documented that in Latin America childbearing is not confined to formal marriages. The multivariate results in Table 4 provide further evidence along the same lines. The presence of children, once age and union order are controlled, does not seem to be a key discriminating factor between informal and formal marriages, although the patterns observed vary across countries. In the Dominican Republic, Peru and Ecuador, the number of children a woman has is not significantly associated with her current union status. In El Salvador, Guatemala, Colombia and Bolivia, women at lower parities -1 or 2 children- are as likely as childless women to be in a consensual union, but women with 3 or more children are more likely to be in a legal marriage. In the two countries where the overall prevalence of consensual unions is lowest, Brazil and Mexico, the chances of being in a consensual union diminish after having a child and decrease monotonically with parity.

Lastly, it is important to note that although our analysis was confined to women because of data availability, the study of union behaviour should ideally be approached from both women's and men's perspectives. More recent DHS surveys, which include female and male samples, allow to explore gender differentials in the determinants of union status. A recent study of consensual unions in Nicaragua found, for instance, that most socioeconomic variables had a similar effect for both men and women, whereas other factors, such as union order or premarital sexual experience, were less relevant among men than women when explaining current union type (Castro Martin, 1999).

\section{SUMMARY ANDDISCUSSION}

The prevalence of consensual unions has been documented to be remarkably high in most Latin American societies, except in the southern countries. Despite their higher instability and the fact that many of them are eventually formalized, a large proportion of consensual unions are longlived and therefore cannot be adequately portrayed as a transient stage of the marital life cycle. More importantly, consensual unions constitute a regular context for bearing and rearing children, blurring the distinction between dejure and defacto marriages. The evidence presented points towards the institutionalization of a dual system of nuptiality, in which two types of partnership, similar in their social recognition and reproductive behaviour, but dissimilar with regard to their long-term legal obligations, stability and safeguard mechanisms, coexist side by side.

Unlike the developed world, where cohabitation gained social visibility only recently, in Latin America, consensual unions have been an integral component of the family system for centuries. Their historical roots can be traced back to the colonial period and the difficulties of imposing the Catholic marriage model on an ethnically and culturally diverse society. Besides this historical and cultural legacy, nuptiality patterns are also influenced by a 
socioeconomic dimension (De Vos, 2000). Although the first half of the century saw a reduction of consensual unions in favour of an institutionalization of marriage (Quilodrán, 1999), the general trend documented here from 1970 onwards does not point towards a continued reduction - except in Guatemala, but to a stabilization of already high levels or a moderate increase. The "lost decade" and the social repercussions of structural adjustment programs may also have recently left their mark on nuptiality patterns (Tapinos, Mason and Bravo, 1997).

The analysis showed that consensual unions are particularly prevalent among younger women and women in their second or higher order union. In fact, in some countries, legal marriage is the exception rather than the norm in these subgroups. The survey data also showed that consensual unions are more prevalent among women with low educational attainment - and with low educated partners, suggesting that lack of assets combined with poor economic prospects may reduce the perceived need for legal regulation. It could also be argued that, because of their poorer bargaining position, women with lower socioeconomic status are compelled to accept unions with little long-term financial support (Glaser, 1999).

In developed countries, cohabitation is usually portrayed as a sign of women's emancipation and as an indication of a weakened normative imperative to marry, induced by a greater emphasis on the quality of the relationship than on institutionalization. In many Latin American societies, however, historical traditions and practical considerations, rather than a deliberate rejection of state or church interference, probably underlie the high prevalence of informal unions. Although there are few data on women's underlying preferences, the higher prevalence of consensual unions among lower educated strata suggests that the type of marital arrangement women end up living in might not always be a matter of choice, but rather the outcome of social constraints. In the Latin American context, legal unions are generally considered more advantageous because they provide greater economic security, besides granting legitimacy and legal protection to family members. Evidence from qualitative studies suggests that although men tend to favour flexible partnerships, women usually state a preference for formal unions, on the basis of their higher stability and better defined economic obligations, even if they settle for an informal union (Greene, 1991). Although no moral judgement is passed, consensual unions are generally regarded as second-order marriages and responsibility for children is the main concern stated (Quilodrán, 1998).

The social consequences of the high prevalence of consensual unions require further study. There is some indication that consensual unions might be unfavourable for the woman, because of loosely defined family responsibilities and the partner's low fmancial commitment in case of dissolution. Since consensual unions are more prevalent in the poorest sectors of society, women who are disadvantaged to begin with are at greatest risk of having to bear sole responsibility for the economic support of their children if the relationship dissolves. There is also evidence that children might be worse off in consensual unions. Some studies have documented higher infant and child mortality (Carvajal and Burgess, 1978) and poorer nutritional status (Desai, 1992) among children whose mothers were in a consensual union, and linked the lower degree of commitment in the relationship to the lower investment in children. Children born in informal marriages may also suffer from limited kinship networks and restricted access to property and inheritance. Although most 
countries have introduced reforms in their legislation in order to equate the rights and duties of partners in consensual and formal unions and to eliminate the discrimination between legitimate and illegitimate children, male responsibilities towards the family are difficult to enforce, particularly after separation or in cases where paternity has not been acknowledged (Budowski and Rosero-Bixby, 1999). Hence, there is a need for further legal provisions to safeguard the interests of both partners in consensual unions and of their offspring and to ensure equal responsibilities and rights.

\section{REFERENCES}

Aldrich, J. H. and F. D. Nelson.

1984 Linear Probability, Logit and Probit Models. Sage University Paper Series on Quantitative Applications in the Social Sciences, No. 07-045, Beverly Hills, CA: Sage Publications.

Arias, E. and A. Palloni.

1999 "Prevalence of female headed households in Latin America: 1970-1990." Journal of Comparative Family Studies 30 (2): 257-279.

Arretx, C.

1971 "Nuptiality in Latin America." Pp. 2127-2152 in Proceedings of the International Population Conference, Vol. 3. Liège: IUSSP.

Blanc, A. K. and N. Rutenberg.

1990 "Assessment of the quality of data on age at first sexual intercourse, age at first marriage, and age at first birth in the Demographic and Health Surveys," DHS Methodological Reports No. 1. Columbia, Maryland: Institute for Resource Development.

Budowski, M. and L. Rosero-Bixby.

1999 "Fatherless Costa Rica: Paternity acknowledgement and child support in Costa Rica." Paper presented at the International Seminar The Population of the Central American Isthmus at the End of the Millennium, Jacó, Costa Rica, October 20-22, 1999.

Bumpass, L. L.

1995 "Cohabitation, marriage and union stability: preliminary findings from NSFH2." National Survey of Families and Household Working Paper No. 65. Center for Demography and Ecology, University of Wisconsin-Madison.

Bumpass L. L. et al.

1991 "The role of cohabitation in declining rates of marriage." Journal of Marriage and the Family 53 (4): 913-927.

Burch, T. K.

1983 "The impact of forms of families and sexual unions and dissolution of unions on fertility." Pp. 532-561 in R. A. Bulatao and R. S. Lee (eds.), Determinants of Fertility in Developing Countries, Vol 2. New York: Academic Press.

Camisa, Z.

1978 "La nupcialidad de las mujeres solteras en la América Latina." Notas de Población 18: 9-76.

Carvajal, M. J. and P. Burgess.

1978 "Socioeconomic determinants of fetal and child deaths in Latin America: a comparative study of Bogota, Caracas and Rio de Janeiro." Social Science and Medicine 12 (3-4): 89-98. 
Castro Martin, T.

1999 "Matrimonios sin papeles en Centroamérica." Paper presented at the International Seminar The Population of the Central American Isthmus at the End of the Millennium, Jaco, Costa Rica, October 20-22, 1999.

Castro Martin, T. and F. Juárez.

1995 "The impact of women's education on fertility in Latin America: searching for explanations." International Family Planning Perspectives 21 (2): 52-57.

Catasús Cervera, $\mathrm{S}$.

1992 "La nupcialidad durante la década de los ochenta en Cuba." Estudios Demográficos y Urbanos 7 (2-3): 465-477.

DeMaris, A.

1995 "A tutorial in logistic regression." Journal of Marriage and the Family 57: 956-968.

Desai, S.

1992 "Children at risk: the role of family structure in Latin America and West Africa." Population and Development Review 18 (4): 698-717.

De Vos, S.

1987 "Latin American households in comparative perspective." Population Studies 41 (3): 501-517.

De Vos, $S$.

1999 "Comment of coding marital status in Latin America." Journal of Comparative Family Studies 30 (1): 79-93.

De Vos, $\mathbf{S}$.

2000 "Nuptiality in Latin America," Pp. 219-243 in S. L. Browning and R. R. Miller (eds.), Till Death Do Us Part: A Multicultural Anthology on Marriage. Stamford, CT: JAI Press.

De Vos, S. and K. Richter.

1988 "Household headship among unmarried mothers in six Latin American countries." International Journal of Comparative Sociology 29 (3-4): 214-229.

Ebanks, G.E. and E. Loaiza.

1989 "Nuptiality and fertility in the Dominican Republic." Journal of Biosocial Science 21: $71-82$.

Folbre, N.

1991 Mothers on Their Own: Policy Issues for Developing Countries. New York: The Population Council, International Center for Research on Women.

Glaser, K.

1994 "Fertility consequences of union choice in Costa Rica: a quantitative and qualitative study." Paper presented at the 1994 Annual Meeting of the Population Association of America, May 5-7, Miami, Florida.

Glaser, K.

1999 "Consensual unions in two Costa Rican communities: an analysis using focus group methodology." Journal of Comparative Family Studies 30 (1): 57-77.

Goldman, N.

1981 "Dissolution of first unions in Colombia, Panama and Peru." Demography 18 (4): 659-679.

Goldman, N. and A. R. Pebley.

1981 "Legalization of consensual unions in Latin America." Social Biology 28 (1-2): 49-61. 
Gonzalbo Aizpuru, P.

1998 Familia y Orden Colonial. México: El Colegio de México, Centro de Estudios Históricos.

Goode, W.J.

1993 "Latin America: a regional system of formal and informal divorce." Chapter 7 in W.J. Goode (ed.), World Changes in Divorce Patterns. New Haven: Yale University Press.

Greene, M. E.

1991 The Importance of Being Married: Marriage Choice and Its Consequences in Brazil. Doctoral Dissertation, University of Pennsylvania.

Greene, M.E. and V. Rao.

1995 "The marriage squeeze and the rise in informal marriage in Brazil." Social Biology 42 (12): 65-82.

Henriques, M. H.

1982 "Legal and consensual Unions: their fertility implications in Latin America." Pp. 271-285 in L. T. Ruzicka (ed.), Nuptiality and Fertility, Liège: Ordina Editions.

Inglehart, $\mathbf{R}$.

1997 Modernization and Post modernization: Cultural, Economic and Political Change in 43 Societies. Princeton, New Jersey: Princeton University Press.

Jelin, E.

1992 "Celibacy, solitude and personal autonomy: individual choice and social constraints," Pp. 109-124 in E. Berqu6 and P. Xenos (eds.), Family Systems and Cultural Change. Oxford: Claredon Press.

Kiernan, K. E.

1996 "Partnership behaviour in Europe: recent trends and issues." Pp. 62-91 in D. Coleman (ed.), Europe's Population in the 1990s. New York: Oxford University Press.

Kuzneof, E. A. and R. Oppenheimer.

1985 "The family and society in nineteenth-century Latin America: an historiographical introduction." Journal of Family History 10: 215-234.

Lavrin, A. (ed.).

1989 Sexuality and Marriage in Colonial Latin America. Lincoln and London: University of Nebraska Press.

Lightbourne, R. E. and S. Singh.

1982 "Fertility, union status and partners in the WFS Guyana and Jamaica surveys, 1975-76." Population Studies 36: 201-225.

Manning W. D.

1993 "Marriage and cohabitation following premarital conception." Journal of Marriage and the Family 55 (4): 839-850.

McCaa, R.

1994 "Marriageways in Mexico and Spain, 1500-1900." Continuity and Change 9 (1): 11-43.

Meekers, D.

1991 "The potential of an increase in consensual unions on fertility: the case of Botswana." Paper presented at the IUSSP Seminar on the Course of Fertility Transition in SubSaharan Africa, 19-22 November 1991, Harare, Zimbabwe.

Michielutte, R. et al.

1973 "Consensual and legal marital unions in Costa Rica." International Journal of Comparative Sociology 14 (1-2): 119-127. 
Nazzari, M.

1996 "Concubinage in colonial Brazil: the inequalities of race, class and gender." Journal of Family History 21 (2):107-124.

Onaka, A., D. Yaukey and A. Chevran.

1977 "Reproductive time lost through marital dissolution in metropolitan Latin America." Social Biology 24: 100-116.

Parrado, E. and M. Tienda.

1997 "Women's roles and family formation in Venezuela: new forms of consensual unions?" Social Biology 44 (1-2): 1-24.

Pescador, J. J.

1988 "Confesores y casaderas: la nupcialidad subyacente en la ética matrimonial de la Iglesia Novohispana." Estudios Demográficos y Urbanos 3 (2). El Colegio de México.

Peyser, A. and J. Chackiel.

1994 "La población indígena en los censos de América Latina." Notas de Población 54: 93-119. CELADE.

Quilodrán, J.

1985 "Modalités de la formation et Évolution des unions en Amérique Latine." Proceedings of International Population Conference, Florence 1985, Liège: IUSSP, vol, 3, pp. 269-283.

Quilodrán, J

1998 Le mariage au Mexique: Évolution naitonale et typologie régionale. Louvain-la-Neuve: Bruyland Academia.

Quilodrdán, J.

1999 "Quand l'union libre n'est pas un phénomène nouveau." Cahiers Québecois de Démographie $28(1-2): 53-80$.

Rao, V. and M. E. Greene.

1991 "Marital instability, inter-spouse bargaining and their implication for fertility in Brazil." Paper presented at the Annual Meeting of the Population Association of America, Washington, D.C.

Richter, $\mathrm{K}$.

1988 "Union patterns and children's living arrangements in Latin America." Demography 25 (4): 553-566.

Rindfuss, R. and A. VanDenHeuvel.

1990 "Cohabitation: a precursor to marriage or an alternative to being single?" Population and Develoment Review 16 (4): 703-726.

Rosero-Bixby, L.

1991 "Premarital sex in Costa Rica: incidence, trends and determinants." International Family Planning Perspectives 17 (1): 25-29.

Rosero-Bixby, L.

1996 "Nuptiality trends and fertility transition in Latin America." Pp. 135-150 in J. M. Guzmán, S. Singh, G. Rodriguez and E. Pantelides (eds.), The Fertility Transition in Latin America. Oxford: Clarendon Press.

Salles, V. and R. Tuiran.

1997 "The family in Latin America: a gender approach." Current Sociology 45 (1): 141-152.

Stycos, J. M.

1968 "Consensual unions and fertility." Pp. 202-214 in J. M. Stycos (ed.), Human Fertility in Latin America: Sociological Perspectives. Ithaca, NY: Cornell University Press. 
Tapinos, G., A. Mason and J. Bravo.

1997 Demographic Responses to Economic Adjustment in Latin America. Oxford: Clarendon Press.

Thiriat, M.P.

1999 "Les unions libres en Afrique subsaharienne." Cahiers Québécois de Démographie 28 (1-2): 81-116.

Trovato, F. and H. W. Taylor.

1980 "The relationship between sex-union type and fertility in Costa Rica: an analysis of census data." International Journal of Sociology of the Family 10 (2): 199-212.

United Nations.

1990 Patterns of First Marriage: Timing and Prevalence. Department of International Economic and Social Affairs, ST/ESA/SER.R/111. New York.

United Nations.

1995 Living Arrangements of Women and Their Children in Developing Countries: A Demographic Profile. United Nations publication, Sales No. E.96.XIII.5. New York.

United Nations Development Programme (UNDP).

1998 Human Development Report 1998. New York, Oxford: Oxford University Press.

van de Kaa, D. J.

1987 "Europe's second demographic transition." Population Bulletin 42 (1). Washington, DC: Population Reference Bureau. 